\title{
PENGENAAN PAJAK PENGHASILAN (PPH) ATAS PERALIHAN HAK ATAS TANAH DAN ATAU BANGUNAN
}

\author{
I Ketut Gede Purnayasa, Ida Ayu Putu Widiati, Luh Putu Suryani \\ Fakultas Hukum, Universitas Warmadewa, Denpasar-Bali, Indonesia \\ ketutpurnayasa74@gmail.com, idaayuputuwidiati@gmail.com, putusuryani099@gmail.com
}

\begin{abstract}
Abstrak
Pengenaan pajak penghasilan atas tanah dan bangunan merupakan pengenaan pajak dengan ketentuan yang berlaku dan dilakukan oleh individu atau badan hukum. Tujuan penelitian ini untuk mengungkapkan pengaturan mengenai pengenaan pajak penghasilan atas peralihan hak atas tanah dan atau bangunan serta mekanisme pengenaan pajak penghasilan atas peralihan hak atas tanah dan atau bangunan. Metode penelitian yang digunakan adalah penelitian hukum normatif dengan pendekatan perundang-undangan dan pendekatan konseptual. Sumber bahan hukum yang digunakan berupa sumber bahan hukum primer, sekunder dan tersier. Bahan-bahan yang telah didapat kemudian dianalisis menggunakan teknik analisis kualitatif yang dimana pengkajiannya dilakukan secara deduktif, guna menghasilkan data yang sifatnya deskriptif analitis. Hasil penelitian mengungkapkan bahwa pengaturan mengenai pengenaan pajak penghasilan atas tanah dan bangunan dilakukan sesuai dengan ketentuan dalam pasal 4 ayat (2) huruf (d) UU PPh, yang dimana pengenaan atas pajak sifatnya mutlak. Atas dasar tersebut pengenaan pajak penghasilan termasuk sifat, besar dan tata cara dalam pembayarannya, serta pemotongan dan pemungutannya diatur PP No. 71 Thn 2008. Dan mekanisme pengenaan atas pajak telah diatur dalam PP No. 34 Tahun 2016 khususnya pada pasal 2 ayat (1).
\end{abstract}

Kata Kunci: Mekanisme, Pajak Penghasilan, Peralihan Hak Atas Tanah dan Bangunan

\begin{abstract}
The imposition of income tax on land and buildings is the imposition of tax with applicable provisions and is carried out by individuals or legal entities. The purpose of this study is to reveal the regulation regarding the imposition of income tax on the transfer of rights to land and or buildings and the mechanism for imposing income tax on the transfer of rights to land and or buildings. The research method used is normative legal research with a statutory approach and a conceptual approach. The sources of legal materials used are primary, secondary and tertiary sources of legal materials. The materials that have been obtained are then analyzed using qualitative analysis techniques where the assessment is carried out deductively, in order to produce data that is descriptive analytical. The results of the study reveal that the regulation regarding the imposition of income tax on land and buildings is carried out in accordance with the provisions in Article 4 paragraph (2) letter (d) of the Income Tax Law, in which the imposition of taxes is absolute. On this basis, the imposition of income tax including the nature, amount and procedure for its payment, as well as its withholding and collection is regulated by PP. 71 Year 2008. And the mechanism of imposition of taxes has been regulated in PP no. 34 of 2016 especially in article 2 paragraph (1).
\end{abstract}

Keywords: Mechanism, Income Tax, Transfer of Land and Building Rights

\section{PENDAHULUAN}

Demi menunjang pembangunan nasional Indonesia memiliki beberapa pemasukan salah satu diantaranya adalah pajak. Pajak merupakan pungutan yang dilakukan atau sifatnya memaksa dan dilakukan untuk kepentingan Negara, serta proses pelaksanaannya telah diatur dalam Undang-undang. Pengaturan mengenai pajak tersebut tercantum dalam UUD 1945 pasal 23 huruf (a). Pajak merupakan sumber pemasukan negara yang memiliki dampak besar dalam memberikan anggaran atas pengeluaran-pengeluaran negara dalam upaya meningkatkan pembangunan nasional dari segala aspek (Sutedi, 2014). Atas dasar tersebutlah diharapkan warga Negara Indonesia memiliki ketaatan terhadap pembayaran pajak dalam bentuk apapun.

Sumber pendapat negara atas pajak diperoleh salah satunya dari pajak penghasilan atas peralihan tanah dan bangunan baik itu dilakukan oleh individu atau badan hukum. Besarnya nilai pembayaran atas pajak penghasilan atas peralihan tanah dan bangunan adalah sebesar $5 \%$ dari bruto nilai pengalihan atas tanah tersebut. Kecuali pengalihan tanah atau bangunan rumah susun yang 
sifatnya sederhana maka dikenakan hanya sebesar $1 \%$ dari bruto nilai tanah dan bangunan tersebut (Adjie, 2009).

Pengalihan terhadap hak penguasaan tanah itu sendiri yang dilakukan oleh individu ataupun badan yang tidak termasuk kedalam subjek pajak. Pajak tersebut diterima atau diperoleh oleh individu itu sendiri dan badan tersebut sesuai dengan yang telah diatur dalam ketentuan UU No. 36 Thn 2008. Pembayaran atas pajak di Indonesia dalam dilakukan melalui 3 cara, yaitu pertama yaitu dengan cara official assessment system, system ini adalah pemberian keleluasaan kepada pemerintah dalam menentukan besar kecilnya pajak yang harus dibayarkan oleh subjek pajak itu sendiri. Pajak yang termasuk ke dalam sistem pembayaran ini adalah pajak yang bersifat pasif, hutang pajak yang timbul akibat dari keterlambatan pembayaran dan diterbitkannya surat atas penetapan pajak tersebut.

Self assessment system merupakan sistem pembayaran dengan memberikan wewenang kepada subjek pajak itu sendiri dalam melakukan penghitungan atas terhadap pajak yang harus dibayarkannya. System ini dalam berjalan apabila subjek pajak rutin melakukan penghitungan terhadap pajak yang harus dibayarkan, melaporkan dan membayar pajak sesuai dengan jumlah yang seharusnya dibayarkan dan pemerintah tidak lagi perlu memberikan surat atas ketetapan pajak kecuali terjadi tindak tertentu, seperti keterlambatan dalam pelaporan dan pembayaran pajak yang dilakukan oleh subjek pajak itu sendiri.

Withholding System merupakan sistem atas pemberian wewenang terhadap pihak lain atau pihak ketiga untuk melakukan penghitungan dan pembayaran pajak oleh subjek pajak. Yang dimaksud pihak ketiga disini adalah orang dianggap mampu dan memiliki kompetensi dalam hal ini dan telah diberikan kepercayaan serta wewenang penuh oleh subjek pajak itu sendiri. Penghitungan atas pajak penghasilan berupa $\mathrm{PPh}$ itu sendiri tertuang dalam pasal 4 ayat (2) $\mathrm{UU} \mathrm{PPh}$, penghitungan atas pajak tersebut berdasarkan atas transaksi dari pengalihan hak terhadap tanah dan bangunan dikenakan sebesar 5\% dari nilai transaksi. Sedangkan apabila transaksi pengalihan hak terhadap tanah tersebut dilakukan secara lelang, maka persentase yang dipakai adalah nilai atau persentase dalam keputusan lelang tersebut (Soemitro, 1987). Pemberian keleluasaan dari pusat ke pemerintah daerah dalam mengembangkan wilayahnya masing-masing atau yang lebih dikenal dengan istilah otonomi daerah mengakibatkan pajak dari BPHTB diserahkan dan dikelola sepenuhnya oleh daerah sesuai dengan ketentuan dan amanat dari UU No. Thn 2009.

Dalam upaya persiapan pengelolaan atas BPHTB, pemerintah daerah membentuk penataan atas struktur organisasi yang akan diberikan wewenang atas pengurusan terhadap pengalihan pajak, dan pembentukan kepengurusan organisasi tersebut sesuai dengan acuan dan kebijakan dari pemerintah pusat. Sumber pendapat Negara atas pajak diperoleh salah satunya dari pajak penghasilan atas peralihan tanah dan bangunan baik itu dilakukan oleh individu atau badan hukum. Besarnya nilai pembayaran atas pajak penghasilan atas peralihan tanah dan bangunan adalah sebesar 5\% dari bruto nilai pengalihan atas tanah tersebut. Kecuali pengalihan tanah atau bangunan rumah susun yang sifatnya sederhana maka dikenakan hanya sebesar $1 \%$ dari bruto nilai tanah dan bangunan tersebut.

Bea Peralehan Hak Atas Tanah dan Bangunan itu sendiri merupakan pajak yang dikenakan atas perolehan hak atas tanah dan bangunan sesuai dengan prosedur dan ketentuan yang berlaku. Nilai pajak atas perolehan ini telah ditetapkan sebesar 5\% dari nilai transaksi dari peralihan tersebut. Penentuan atas tariff sebesar 5\% ini dilakukan agar lebih sederhana dan lebih mudah dalam melakukan perhitungan. Sistem dalam pembayaran pajak selain yang termuat dalam UU yang telah disebutkan diatas banyak mengalami pembaharuan, baik itu dari sistem pembayaran, teknis dan prosedur pembayaran dan diharapkan pihak terkait dapat membimbing para subjek pajak dalam menjalani perubahan-perubahan tersebut, agar subjek pajak dapat melakukan kewajibannya sebagaimana mestinya dalam membayar PPh dan BPHTB.

Terdapat penelitian sebelumnya yang relevan dengan penelitian ini. (Mustika et al., 2020) berpendapat bahwa kebijakan pemerintah dalam menetapkan pengenaan Pajak Penghasilan $(\mathrm{PPh})$ atas Pengalihan Hak atas Tanah atau bangunan yang diikat dalam Perjanjian Pengikatan Jual Beli (PPJB) adalah guna mencegah terjadinya penghindaran pajak dan sebagai sarana mempercepat pemasukan negara. Sedangkan (Sulbahri \& Sari, 2018) mengatakan bahwa pajak atas pengahasilan dari pengalihan hak atas tanah atau bangunan dalam operasionalnya harus memperhatikan dengan seksama faktor-faktor kesederhanaan, tarif, sistem pemungutan, peniadaan pengenaan pajak ganda, pemerataan 
dalam pengenaan dan pembebanan, kepastian hukum, menutup peluang penggelapan pajak dan penyalahgunaan wewenang, serta dapat pula mendorong kegiatan ekonomis dan menutup praktekpraktek spekulasi tanah sehingga kehadirannya dapat diterima dan diakui oleh masyrakat karena saling menguntungkan. Adapun kepastian hukum dalam pengenaan pajak penghasilan atas penghasilan dari transaksi jual beli tanah dan/atau bangunan saat ini telah diatur dalam PP Nomor 34 Tahun 2016 dengan tarif sebesar 2,5\% (Iswara et al., 2019).

Berdasarkan uraian diatas, maka tujuan penelitian ini yaitu untuk mengungkap pengaturan mengenai pengenaan pajak penghasilan atas peralihan hak atas tanah dan atau bangunan serta mekanisme pengenaan pajak penghasilan atas peralihan hak atas tanah dan atau bangunan.

\section{METODE PENELITIAN}

Penelitian ini termasuk kedalam penelitian hukum normatif, yang dikaji menggunakan studi kepustakaan yang berupa bahan-bahan hukum dan berdasar pada norma-norma yang ada. Pendekatan masalah yang digunakan dalam penelitian ini adalah pendekatan perundang-undangan dan pendekatan konseptual yang menekankan pada pandangan dan doktrin-doktrin yang berkembang dalam ilmu hukum. Teknik pengumpulan bahan hukum yang digunakan adalah bahan hukum primer yang didapat dengan menganalisis peraturan perundang-undangan, risalah resmi, dan beberapa keputusan-keputusan yang menyangkut dengan judul tulisan ini. bahan hukum sekunder didapat dari menganalisis buku-buku, jurnal-jurnal dan hasil-hasil penelitian terdahulu yang memiliki keterkaitan dengan judul penulisan ini. Dan bahan hukum tersier yang dapat menunjang bahan hukum primer dan sekunder seperti kamus-kamus hukum dan tulisan yang dapat diakses melalui internet. Bahan-bahan yang telah didapat kemudian dianalisis menggunakan teknik analisis kualitatif, yang dimana teknik ini dilakukan dengan cara mengolah data yang telah diperoleh dari hasil penelitian dan kemudian diseleksi berdasarkan dari kualitas data tersebut dan disesuaikan dengan penelitian yang dimana pengkajiannya dilakukan secara deduktif, guna menghasilkan data yang sifatnya deskriptif analitis. Dan data yang telah diperoleh disusun dan dilaporkan sebagaiman mestinya, sehingga dapat memberikan sebuah kesimpulan yang logis.

\section{HASIL DAN PEMBAHASAN}

\section{Pengaturan Mengenai Pengenaan Pajak Penghasilan Atas Peralihan Hak Atas Tanah dan atau Bangunan}

Pajak merupakan sumber pemasukan negara yang memiliki dampak besar dalam memberikan anggaran atas pengeluaran-pengeluaran negara dalam upaya meningkatkan pembangunan nasional dari segala aspek. Atas dasar tersebutlah diharapkan warga Negara Indonesia memiliki ketaatan terhadap pembayaran pajak dalam bentuk apapun. Sedangkan pajak penghasilan merupakan pajak yang dipungut langsung oleh pemerintah pusat. Pungutan langsung tersebut menjadi tanggungjawab penuh subjek pajak yang bersangkutan., dalam konteks ini pembayaran atas pajak penghasilan tidak boleh dilimpahkan kepada pihak lain atau dimasukkan langsung kedalam harga jual dan harga produksi (Nurmantu, 2003).

Adapun yang menjadi subjek dari pajak penghasilan itu sendiri adalah mereka yang memiliki penghasilan dan memiliki potensi untuk dikenakan pajak penghasilan tersebut. Jika subjek pajak telah melakukan pemenuhan atas pembayaran pajak tersebut, maka subjek pajak dapat dikatakan sebagai wajib pajak. Wajib pajak adalah subjek pajak yaitu orang atau badan yang telah dengan taat melakukan kewajibannya dalam membayar pajak sesuai dengan jumlah dan waktu yang telah ditentukan sesuai dengan ketentuan dan prosedur hukum yang berlaku. Yang dapat dikategorikan ke dalam subjek pajak adalah orang pribadi, warisan, badan dan bentuk usaha tetap (Suandy, 2011). Orang pribadi merupakan mereka yang berdiam atau bertempat tinggal di wilayah Indonesia ataupun di luar wilayah Indonesia, tidak melihat batasan usia, status social, kewarganegaraan dan kewarganegaraan.

Dalam upaya persiapan pengelolaan atas BPHTB, pemerintah daerah membentuk penataan atas struktur organisasi yang akan diberikan wewenang atas pengurusan terhadap pengalihan pajak, dan pembentukan kepengurusan organisasi tersebut sesuai dengan acuan dan kebijakan dari pemerintah pusat. Badan merupakan sekumpulan orang atau modal baik yang melakukan usaha ataupun yang 
tidak melakukan usaha, contohnya perseroan terbatas, perseroan komanditer, koperasi, yayasan dan segala bentuk badan lainnya baik itu badan yg berbentuk hukum ataupun tidak. Bentuk usaha yang dapat dikatakan tetap adalah bentuk usaha yang digerakkan oleh individu yang merupakan warga Negara Indonesia maupun individu yang telah berdiam di Indonesia kurang lebih selama 12 bulan atau badan yang tidak didirikan di Indonesia untuk mendirikan dan menjalankan usahanya di Indonesia.

Pengalihan hak terhadap tanah dan bangunan itu sendiri merupakan proses dari penjualan, pelepasan atau penyerahan hak atau cara lain yang telah disepakati bersama dengan pemerintah dengan tujuan membantu menunjang kepentingan umum. Dalam upaya persiapan pengelolaan atas BPHTB, pemerintah daerah membentuk penataan atas struktur organisasi yang akan diberikan wewenang atas pengurusan terhadap pengalihan pajak, dan pembentukan kepengurusan organisasi tersebut sesuai dengan acuan dan kebijakan dari pemerintah pusat. Apabila pembayaran pajak telah dilakukan oleh subjek pajak, bendaharawan dan pejawab wajib melakukan penyetoran atas pembayaran PPh tersebut ke bank ataupun kantor pos sebelum melakukan pembayaran ke individu atau badan yang berhak atas pembayaran tersebut (Widyaningsih, 2011). Setelah proses pembayaran bendaharawan atau pejabat wajib melakukan pelaporan atas pengalihan hak terhadap tanah kepada direktorat jenderal pajak.

Pengenaan jumlah pajak yang harus dibayarkan dalam proses peralihan, prosedur peralihan dan penandatanganan telah diatur dalam PP No 71 Tahun 2008 yang mengatur tentang PPh. PP No. 71 Tahun 2008 pada pasal 2 menyebutkan bahwa dalam pembayaran pajak penghasilan haruslah dilakukan sebelum proses penandatanganan akta atas peralihan tanah tersebut. Perolehan hak atas tanah itu sendiri merupakan peristiwa hukum yang mengakibatkan timbulnya perolehan atas hak dari tanah itu sendiri baik oleh pribad ataupun badan. Hak atas tanah dan bangunan itu sendiri merupakan hak atas kepemilikan, hak atas pengelolaan baik itu tanah atau bangunan diatasnya, seperti yang telah tertuang dalam UU No. 5 Tahun 1960 (yang selanjutnya disebut UUPA). Dan pengaturan mengenai pembayaran pajak atas hak tersebut termuat dalam UU PPh. Dengan berkembangnya zaman, maka system dalam pembayaran pajak selain yang termuat dalam UU yang telah disebutkan diatas banyak mengalami pembaharuan, baik itu dari sistem pembayaran, teknis dan prosedur pembayaran dan diharapkan pihak terkait dapat membimbing para subjek pajak dalam menjalani perubahan-perubahan tersebut, agar subjek pajak dapat melakukan kewajibannya sebagaimana mestinya dalam membayar PPh dan BPHTB.

\section{Mekanisme Pengenaan Pajak Penghasilan Atas Peralihan Hak Atas Tanah dan atau Bangunan}

Peralihan hak atas tanah itu sendiri merupakan perbuatan hukum dalam hal pemindahan hak atas yang dilakukan dengan sengaja agar hak atas tanah tersebut lepas dari pemilik sebelumnya dan beralih ke pemiliknya yang baru. Dengan beralihnya hak tersebut, maka menunjukan terjadinya perbuatan hukum yang dilakukan secara sengaja oleh satu pihak untuk mengalihkan hak atas tanah yang dimilikinya kepada pihak lainnya. Pasal 37 PP No 24 Tahun 1997 mengatakan bahwa proses dari peralihan hak atas tanah tersebut dapat terjadi dengan cara melakukan proses atau transaksi jual beli, tukar menukar, hibah, pemasukan dalam suatu perusahaan dan perbuatan hukum lainnya yang mengakibatkan terjadinya pemindahan terhadap suatu hal terkecuali lelang, Karena dalam lelang pemindahan atas hak tersebut dapat dibuktikan dengan menunjukan bukti akta dari PPAT yang berwenang sesuai dengan ketentuan dari Undang-undang itu sendiri (Harsono, 2012).

Pendaftaran tanah atas proses peralihan dari pemilik sebelumnya ke pemilik barunya sangatlah penting, pendaftaran tanah merupakan kegiatan yang dilakukan secara berkesinambungan oleh subjek hukum dengan tujuan memperoleh kepastian atas kepemilikan dari sebidang tanah dan bangunan. Pendaftaran tanah di Indonesia dilakukan oleh Badan Pertanahan Nasional yang telah disahkan oleh UU No. 10 Tahun 2006 (Sutedi, 2014). BPN sebagai instansi yang bertugas dalam melakukan pendaftaran atas tanah, BPN harus melakukan pengolahan data dari buku kepemilikan tanah yang telah didaftarkan agar tidak terjadi sengketa dalam pendaftaran tanah yang dilakukan kedua kalinya. Selain melalui proses jual beli, waris dan hibah, hak milik juga dapat terjadi dikarenakan adanya 
penetapan pemerintah yang diberikan oleh instansi-instansi berwenang sesuai dengan ketentuan yang berlaku.

Pengalihan hak atas tanah, secara khusus hak milik dapat terlaksana dengan benar apabila PPAT melakukan dan memastikan atas kebenaran hak milik tersebut dan mengenai kewenangannya akan bertindak dalam proses pengalihan hak milik tersebut dan harus memastikan kebenaran dari dokumen peralihan hak tersebut. Pengenaan pajak penghasilan dalam proses peralihan hak atas tanah dan bangunan tersebut diatur dalam PP No. 34 Thn 2016. Peraturan tersebut mulai dinyatakan berlaku setelah 30 hari peraturan tersebut diundangkan. Dan peraturan yang menjadi turunan dari PP No. 34 Tahun 2016 dalam hal pengenaan pajak penghasilan adalah PMK No. 261/PMK/03/2016 Tentang tata cara dari penyetoran, pelaporan dan pengecualian atas pengenaan pajak hak atas tanah dan bangunan.

Transaksi atas pengalihan hak ini terutama yang berupa rumah sederhana dan rumah susun dilakukan oleh wajib pajak dengan dikenakan tarif sebesar 1\%. Dan taris sebesar 2,5\% dikenakan bagi transaksi peralihan yang dilakukan oleh wajib pajak yang memang pekerjaan pokoknya melakukan peralihan hak atas tanah dan bangunan. Dalam pengenaan pajak atas peralihan hak atas tanah dan bangunan didalamnya ada istilah yang dinamakan PTKP atau yang lebih dikenal dengan Penghasilan Tidak Kena Pajak. PTKP ini merupakan pengalihan hak atas tanah dengan jumlah transaksi atau bruto sebesar Rp. 60.000.000. Berdasarkan ketentuan ini maka wajib pajak tersebut tidak dapat dikenakan PPh atas peralihan hak atas tanahnya, beberapa tahap yang memang harus dipenuhi oleh wajib pajak dalam memperoleh haknya tersebut.

\section{SIMPULAN DAN SARAN}

\section{Simpulan}

Pengaturan mengenai pengenaan pajak PPh telah diatur dalam pasal 4 ayat (2) UU PPh. Atas dasar pengaturan tersebutlah sifat, besarnya pembayaran, pemotongan atau pemungutan dari jenis-jenis penghasilan dan tata cara serta mekanisme pembayaran telah diatur secara rinci dalam UU $\mathrm{PPh}$. Pengaturan atas pembayaran pajak penghasilan tersebut dilaksanakan berlandaskan asas charity yang dimana artinya kepastian bukan hanya menyangkut subjek pajak, objek pajak dan tarif pajak, melainkan juga mengenai pemenuhan atas kewajiban dan tata cara atau prosedur pembayaran dan pelaporan serta pelaksanaan hak-hak perpajakan. Adapun mekanisme pengenaan jumlah pembayaran pajak dihitung dari bruto nilai atas pengalihannya. Yang dapat dikatakan nilai bruto tersebut adalah nilai atau nominal yang tercantum dalam ketentuan lelang, nilai atau jumlah uang yang seharusnya diperoleh dalam transaksi jual beli, nilai atau nominal yang harus diterima apabila terjadi transaksi dalam proses tukar menukar dan nilai dasar dari pengalihan yang telah ditetapkan oleh petugas yang berwenang.

\section{Saran}

Kepada pemerintah disarankan agar BPN lebih sering memberikan sosialisasi bagi masyarakat akan pentingnya melakukan pembayaran pajak peralihan hak atas tanah dan bagi pemerintah kabupaten/kota diharapkan agar memberikan pemahaman akan kesabaran melakukan pembayaran pajak kepada masyarakatnya serta diharapkan agar memberikan pelayanan yang layak bagi masyarakatnya sesuai dengan ketentuan yang berlaku. Hendaknya apabila ada ketentuan baru atau perubahan terhadap mekanisme dan ketentuan dalam melakukan pembayaran pajak $\mathrm{PPh}$, pihak terkait diharapkan memberikan pemahaman bagi masyarakat akan perubahan tersebut supaya tidak menimbulkan kebingungan dari masyarakat saat ingin mendaftarkan peralihan hak atas tanah mereka. Diharapkan agar pengenaan pajak peralihan atas tanah sesuai dengan ketentuan dari peraturan perundang-undangan yang berlaku dan disesuaikan dengan jumlah transaksi masyarakat dalam proses peralihan hak atas tanah tersebut.

\section{DAFTAR PUSTAKA}

Adjie, H. (2009). Meneropong Khazanah Notaris dan PPAT Indonesia. Citra Aditya, Bandung. Harsono. (2012). Perkembangan Pengaturan Kewarganegaraan. Liberty, Yogyakarta.

Iswara, I. G. N. B. M., Nahak, S., \& Mahendrawati, N. L. M. (2019). Kepastian Hukum Pengenaan Pajak Penghasilan Transaksi Jual Beli Tanah dan/atau Bangunan. Jurnal Hukum Prasada, 6(1), 
$42-51$.

Mustika, N., Sugiharti, D. K., \& Trisnamansyah, P. (2020). Pengenaan Pajak Penghasilan Atas Pengalihan Hak Atas Tanah dan/atau Bangunan yang diikat Dalam Perjanjian Pengikatan Jual Beli dihubungkan dengan Ease Of Doing Business (Eodb) Dalam Perspektif Kepastian Hukum. Jurnal Poros Hukum Padjajaran, 1(2), 172-190.

Nurmantu, S. (2003). Pengantar Perpajakan. Obor Indonesia, Jakarta.

Soemitro. (1987). Pengantar Singkat Hukum Pajak. Eresco, Bandung.

Suandy, E. (2011). Hukum Pajak. Salemba Empat, Jakarta.

Sulbahri, R. A., \& Sari, I. P. (2018). Analisis Pemungutan PPh Final Atas Pengalihan Hak Atas Tanah dan/atau Bangunan (Pada Studi Kasus Perusahaan Developer PT. Indojaya Agung Property Palembang). Jurnal ACSY Politeknik Sekayu, 7(2), 74-84.

Sutedi, A. (2014). Peralihan Hak Atas Tanah dan Pendaftarannya. Sinar Grafika, Jakarta.

Widyaningsih, A. (2011). Hukum Pajak Dan Perpajakan Dengan Pendekatan Mind Map. Alfabeta, Bandung. 